\title{
PENGARUH PENERAPAN SAP DAN SPIP TERHADAP KUALITAS LAPORAN KEUANGAN PEMERINTAH DAERAH KOTA BOGOR DENGAN KOMPETENSI SDM SEBAGAI VARIABEL MODERATING
}

\author{
INFLUENCE OF THE APPLICATION OF GOVERNMENT ACCOUNTING STANDARD AND \\ GOVERNMENT INTERNAL CONTROL SYSTEM ON THE QUALITY OF LOCAL GOVERNMENT \\ FINANCIAL STATEMENTS IN BOGOR CITY WITH THE COMPETENCE OF HUMAN RESOURCES AS A \\ MODERATING VARIABLE
}

\author{
A.B.Setiawan, R.P.Tami \\ Jurusan Akuntansi Fakultas Ekonomi Universitas Djuanda \\ E-mail : ade.budi.@setiawan, rizki.putra.tami@unida.ac.id
}

\begin{abstract}
Local goverment financial statement in Bogor City for the last five years are still given fair opinion with the exception by BPK. This research aims to determine effect of application Government Accounting Standards, and the Government Internal Control System on the quality of local goverment financial statement in Bogor City with the Competence of Human Resources as moderating variable. The method of this research design is using survey methods with data collection method using questionnaires. The population in this research were employees in 39 financial administration officials in Regional Work unit (SKPD) of Bogor City, with using purposive sampling technique, so that the selected 195 employees that the research sample. The analysis technique used is MRA. The result of the analysis showed that simultan test or partial test, application of the Government Accounting Standards and Government Internal Control System have significant impact on the quality of local government financial statement. The competence of human resources as moderating variables can moderated the effect of the Government Accounting Standards and Government Internal Control System on the quality of local government financial statement. Coefficient of determination of 61,4 percent, while the rest 38,6 percent is explained by other variables.
\end{abstract}

Keywords : Government Accounting Standards, Government Internal Control System, Human Resource Competencies, Quality of Financial Statement.

\begin{abstract}
ABSTRAK
Laporan keuangan pemerintah Kota Bogor selama lima tahun terakhir masih diberikan opini WDP oleh BPK. Penelitian ini bertujuan untuk mengetahui pengaruh penerapan SAP dan SPIP terhadap kualitas laporan keuangan pemerintah daerah Kota Bogor dengan Kompetensi SDM sebagai Variabel Moderating. Desain penelitian ini memakai metode survey dengan metode pengumpulan data menggunakan kuisoner. Populasi dalam penelitian ini ialah pegawai di 39 Satuan Kerja Perangkat Daerah (SKPD) di Kota Bogor. Teknik pengambilan sampel memakai purposive sampling, sehingga terpilih 195 pegawai yang dijadikan sampel penelitian. Teknik analisis yang dipakai ialah MRA. Hasil analisis yang dilakukan menunjukan secara simultan ataupun parsial penerapan SAP dan SPIP berpengaruh signifikan terhadap kualitas laporan keuangan pemerintah daerah. Kompetensi SDM sebagai variabel moderasi mampu memoderasi pengaruh SAP dan SPIP terhadap kualitas laporan keuangan pemerintah daerah. Koefisien determinasi sebesar 61,4 persen, sisanya 38,6 persen dijelaskan oleh variabel lain.
\end{abstract}

Kata kunci: SAP, SPIP, Kompetensi SDM, Kualitas Laporan Keuangan. 


\section{PENDAHULUAN}

Kualitas laporan keuangan pemerintah daerah bisa diketahui dari opini yang diberikan oleh Badan Pemeriksa Keuangan (BPK) dengan bentuk opini disclaimer (TMP), opini Tidak Wajar (TW), opini Wajar Tanpa Pengecualian (WTP), dan opini Wajar Dengan Pengecualian (WDP). LKPD memiliki kandungan informasi yang nantinya dipakai oleh pihak ekstern untuk pengambilan keputusan. konsekuensinya informasi dalam LKPD harus memenuhi ukuran-ukuran normatif yang perlu diwujudkan diantaranya relevan, andal, bisa dibandingkan, dan dapat mudah dipahami. Kualitas LKPD bisa ditentukan oleh SAP, SPIP, ketidakpatuhan terhadap perundang-undangan, serta kompetensi SDM.

Halim dan kusufi (2014: 227) menyatakan standar akuntansi merupakan aturan utama yang menjadi pedoman dalam penyajian laporan keuangan, serta pemersatu presepsi antara auditor, pengguna serta penyusun LK. SAP disusun berdasarkan PP Nomor 71 Tahun 2010 mengenai SAP. Kriteria kualitas LKPD selanjutnya bisa ditentukan oleh sistem pengendalian intern. Menurut PP No 60 Tahun 2008 SPIP ialah proses integral pada aktivitas yang diterapkan terus menerus oleh semua pihak untuk memberikan keyakinan atas terpenuhinya visi misi organisasi. Pengendalian internal terbentuk dari 5 unsur pembangun yaitu (1) lingkungan pengendalian (2) penilaian risiko (3) aktivitas pengendalian (4) communication and information (5) monitoring. Kompetensi SDM adalah kemampuan SDM dalam menyelesaikan pekerjaan yang diberikan memakai bekal pengalaman, training, serta pendidikan. Proses pembuatan LK yang akurat membutuhkan KSDM yang menguasai Akuntansi Pemerintahan. Selama 5 tahun ini secara keseluruhan opini LKPD mengalami perbaikan, termasuk LKPD berdasarkan tingkat Pemda yaitu kota. Pemerintah Kota Bogor justru mengalami stagnansi dalam mendapatkan pendapat WTP. Mengingat selama lebih dari 5 tahun kebelakang (2011-2015) Pemkot Bogor belum pernah mendapat opini WTP. Untuk semester satu di tahun anggaran 2015 BPK kembali menetapkan pendapat WDP kepada Pemkot Kota Bogor, dengan akun pengecualian fixed asset dan piutang PBB, 12 temuan terkait SPIP, Kendala aset di Dinas Pendidikan Sehingga harus dilakukan pengadaan SDM yang mengurusi aset. Dari hal tersebut penulis merasa terdorong melaksanakan penelitian dengan judul "Pengaruh Penerapan SAP dan SPIP terhadap Kualitas Laporan Keuangan Pemerintah Daerah Kota Bogor dengan Kompetensi SDM sebagai Variabel Moderating".

\section{TINJAUAN TEORI DAN PENGEMBANGAN HIPOTESIS}

\section{Agency Theory}

Halim \& Kusufi (2014:162) konsep keagenan adalah hubungan kontrak diantara principal dan agent. Principal menugaskan agent dapat bertindak selaras dengan keinginan principal. Pemda dan pusat selaku pengatur sumber daya ekonomi bertindak sebagai agent yang mempunyai keharusan untuk menampilkan informasi dari laporan keuangan yang useful untuk pengguna eksternal (principal).

\section{Kualitas Laporan Keuangan Pemerintah Daerah}

PSAP No satu Paragraf 9 menyatakan laporan keuangan ialah laporan yang tersistematis mengenai transaksi-transaksi dan posisi keuangan yang dilaksanakan oleh entitas pelaporan. Laporan keuangan terbagi atas budgetary report (laporan pelaksanaan anggaran) dan laporan finansial.

Dalam PP No 71 Tahun 2010 karakteristik kualitatif dari laporan keuangan tercantum sebagai berikut :

1. Relevan

2. Andal

3. Dapat Dibandingkan

4. Dapat Dipahami

\section{Standar Akuntansi Pemerintah (SAP)}

Bastian (2010: 138) SAP merupakan pedoman-pedoman akuntansi yang mengatur perlakuan akuntansi didalam pembuatan laporan keuangan Pemda maupun pusat. Terbitnya PP No 71 Tahun 2010 dan 
Pemendgri No 64 Tahun 2013 mengharuskan LKPD disusun berdasarkan basis akrual. Selanjutnya SAP mengatur mengenai pengakuan, pengukuran dan pengukapan.

\section{PSAP (Pernyataan Standar Akuntansi Pemerintah)}

Pemendagri No 64 Tahun 2013 menyatakan PSAP merupakan SAP yang diberi judul, nomor dan tanggal efektif. PSAP termuat pada lampiran satu PP No 71 Tahun 2010, dengan rincian :

1. PSAP 01 Penyajian LK

2. PSAP 02 LRA Berbasis Kas

3. PSAP 03 LAK

4. PSAP 04 CaLK

5. PSAP 05 Inventory

6. PSAP. 06 Akuntansi Investasi

7. PSAP 07 Fixed Asset

8. PSAP 08. KDP

9. PSAP. 09 Kewajiban

10. PSAP 10 Koreksi kesalahan, Operasi yang Tak Dilanjutkan, Perubahan Estimasi serta Kebijakan Akuntansi.

11. PSAP 11 LK Konsolidasi.

12. PSAP LO.

\section{Kebijakan Akuntansi Pemerintah Daerah}

Menurut Pemendagri No 64 Tahun

2013 Pasal 1 ayat (6) kebijakan akuntansi adalah penggunaan praktik yang spesifik oleh entitas dalam menyajikan laporan keuangan. Kebijakan akuntansi pemerintah daerah mengambil inti-inti dari SAP yang diatur dalam PP No 71 Tahun 2010.

\section{Sistem Pengendalian Intern Pemerintah}

PP No 60 Tahun 2008 tentang SPIP menyatakan SPIP ialah proses integral pada aktivitas-aktivitas yang diterapkan dengan terus menerus oleh pimpinan dan semua pihak untuk memberikan suatu keyakinan atas terpenuhinya visi misi organisasi. Mahmudi (2011:252) SPIP bertujuan mengahasilkan laporan keuangan akurat, relevan, dan andal.

\section{Unsur-unsur Sistem Pengendalian Intern Pemerintah}

PP No 60 Tahun 2008 menyatakan SPIP meliputi :

1. Lingkungan pengendalian

2. Penilaian resiko
3. Kegiatan pengendalian

4. Communication and information

5. Pemantauan pengendalian intern

\section{Kompetensi SDM}

Widodo dalam Tantriani (2012) menjelaskan kompetensi SDM adalah kemampuan SDM dalam menyelesaikan pekerjaan yang dilimpahkan kepadanya melalui bekal pengalaman, pendidikan serta training.

\section{Pengaruh Penerapan SAP Terhadap Kualitas LKPD}

SAP dijadikan pedoman dalam melakukan pelaporan transaksi yang terjadi pada aktivitas penyelengaraan pemerintahan. Untuk itu, bentuk pertanggungjawaban atas pengelolaan keuangan negara tersebut ditunjukan dengan pembuatan LKPD yang beracuan pada SAP. LKPD digunakan sebagai akses informasi bagi pihak yang berkepentingan untuk dijadikan dasar pengambilan keputusan, maka informasi dalam LKPD harus useful. SAP membantu informasi mudah dipahami, karena presepsi antara penyusun dan pihak eksternal memiliki kesamaan. Mahmudi (2011:271) SAP diperlukan untuk meningkatkan kualitas LK yaitu meningkatkan konsistensi, daya banding, keterpahaman, relevansi, dan keandalan. Bastian (2010: 138) penerapan SAP yang sesuai dalam pelaporan keuangan daerah merupakan penentu kualitas dari LKPD yang dihasilkan, dan mempunyai kekuatan hukum dalam upaya menigkatan kualitas LKPD. Dengan diimplementasikannya SAP diharapkan akan membantu transparansi, partisipasi, dan akuntanbilitas pengelolaan keuangan negara, sehinga mewujudkan good governance.

$\mathrm{H}_{1}$ : Diduga Penerapan SAP berpengaruh terhadap Kualitas LKPD Kota Bogor.

\section{Pengaruh Penerapan SPIP Terhadap Kualitas LKPD}

SPIP ialah bentuk monitoring pemerintah dalam mengendalikan pengelolaan keuangan negara agar dilaksanakan 
transparan. SPIP memberi pengawasan dalam pemanfaatan sumber ekonomi, sehingga tujuan dapat dicapai, diperolehnya efisiensi kegiatan, pelaporan keuangan yang andal, meniadakan tindak kecurangan, dan kerugian materil. Untuk itu diperlukan komitmen pimpinan organisasi dan bawahanya dalam penyelengaran pemerintahan yang berorientasi pada pencapaian tujuan termasuk transparansi dan akuntabilitas pengelolaan sumber daya ekonomi. Untuk itu auditor Inspektorat dibentuk sebagai aparat yang berwenang dalam melakukan pengawasan, SPIP sendiri diadopsi dari sebuah konsep dari grup studi yaitu The Committee of Sponsoring Organization of the Treadway Commission (COSO). Selanjutnya implementasi SPIP yang efektif dapat menghindarkan kesalahan pembuatan LKPD. Mahmudi (2011:252) SPIP bertujuan mengahasilkan LK yang akurat, relevan, dan andal serta memajukan efisiensi dan efektivitas kegiatan. Dengan demikian SPIP memberikan arahan untuk dihasilkannya LKPD yang sesuai dengan prinsip akuntansi berterima umum. PP No 60 Tahun 2008 menyatakan SPIP ialah aktivitas yang diterapkan terus menerus oleh pimpinan dan semua pihak untuk memberikan keyakinan atas terpenuhinya visi misi organisasi melalui kegiatan efektif dan efisien, keandalan pelaporan keuangan, pengamanan aset negara dan ketaatan terhadap peraturan perundangundangan.

$\mathrm{H}_{2}$ : Diduga SPIP berpengaruh terhadap Kualitas LKPD Kota Bogor.

\section{Kompetensi SDM Memoderasi Pengaruh Penerapan SAP dan SPIP Terhadap Kualitas LKPD}

SDM menjadi faktor penting dalam pelaporan keuangan. Dibutuhkan SDM yang berkompeten yang dapat memahami dengan baik penerapan SAP untuk membuat LKPD. SDM yang mempunyai background akuntansi lebih mampu menghasilkan pelaporan keuangan yang mudah dipahami, sesuai dengan SAP serta menciptakan efesiensi waktu pembuatannya. SDM yang mengikuti training diharapkan akan mempunyai keahlian yang lebih baik, ditambah berpengalaman bisa dibilang SDM yang berkompeten. Dengan begitu SDM akan memahami logika akuntansi dengan benar. Halim \& Kusufi (2014:211) dukungan SDM yang berkompeten menjadi pendukung diterapkannya SAP akrual dalam pengelolaan keuangan, sehingga permasalahan yang ada dapat dihadapi.

Pemahaman SPIP yang tepat akan tercipta dari SDM yang mempunyai pengetahuan dan kompetensi yang mendukung. Pemahaman yang tepat memungkinkan SPIP diimpelementasikan secara konsisten dan sesuai aturan. Selanjutnya SDM yang mempunyai pemahaman SPIP yang baik akan memberikan hasil (output) yang maksimal. Arens (2012:290) tujuan entitas dicapai maksimal diperoleh melewati upaya pengendalian yang diterapkan oleh SDM yang mempunyai kemampuan secara efisien juga efektif. Dengan demikian penerapan SPIP dibutuhkan SDM yang mampu memahami dengan baik PP No. 60 tahun 2008, serta dapat mengimplementasikannya dalam penciptaan akuntabilitas dan transparansi pelaporan keuangan. Sehingga dalam penyusunan LKPD dengan penerapan SAP melalui implementasi SPIP yang efektif yang dilakukan oleh SDM yang kompeten akan menghasilkan LKPD yang berkualitas

$\mathrm{H}_{3}$ : Diduga KSDM memoderasi pengaruh SAP dan SPIP terhadap LKPD Kota Bogor.

\section{METODE PENELITIAN}

Objek penelitian adalah penerapan SAP dan SPIP pada kualitas LKPD Kota Bogor, serta kompetensi SDM yang dapat memperkuat atau memperlemah hubungan. Penelitian ini terkategori dalam penelitian survei deskriptif, dengan teknik explanatory.

\section{Variabel Penelitian dan Operasionalisasi Variabel}

Variabel Independen, yaitu SAP $\left(X_{1}\right)$ dan SPIP $\left(X_{2}\right)$. Variabel Dependen, yaitu 
kualitas LKPD (Y). Variabel Moderating, yaitu Kompetensi SDM (Z). Indikator dari Kualitas LKPD, meliputi : dapat dibandingkan, dapat dipahami, relevan serta andal

\section{Populasi, Sampel dan Teknik Pengambilan Sampel}

Populasi yang dipilih adalah 39 SKPD yang berada di lingkungan Pemrintah kota Bogor. Teknik yang dipilih ialah purposive sampling, dengan total sampel 195.

\section{Metode Pengujian Data}

\section{Metode Skala Pengukuran}

skala likert berisikan lima pilihan jawaban. Bobot nilai yang dipakai pada setiap pernyataan adalah :

Tabel 1 : Penilaian Kuisoner

\begin{tabular}{cc}
\hline Bobot Nilai & Jawaban Responden \\
\hline 1 & Sangat Tidak Setuju \\
2 & Tidak Setuju \\
3 & Kurang Setuju \\
4 & Setuju \\
5 & Sangat Setuju \\
\hline
\end{tabular}

Sumber: Sugiyono (2016: 169)

kriteria penilaian pada tabel berikut ini :

Tabel. 2 : Skala Penilaian

\begin{tabular}{cc}
\hline Skala & Interprestasi \\
\hline $1,00-1,80$ & Sangat Tidak Baik \\
$1,81-2,60$ & Tidak Baik \\
$2,61-3,40$ & Cukup \\
$3,41-4,20$ & Baik \\
$4,20-5,00$ & Sangat Baik \\
\hline Sumber : Sugiyono, 2012 dimodifikasi
\end{tabular}

Sumber : Sugiyono, 2012 dimodifikasi

\section{Analisis Statistik Deskriptif}

Sugiyono (2016:238) statistik deskriptif adalah statistik yang dipakai dengan fungsi menggambarkan data yang sebelumya diperoleh termasuk mean, sum, standar deviasi, dan variance.

\section{Metode Pengujian Instrumen Pengujian Validitas}

Ghozali (2016:52) uji validitas diujikan untuk mengukur valid tidaknya suatu kuisoner.

Tabel 3 : Kriteria Uji Validitas

\section{Corected Item Total Keterangan Corelation}

\begin{tabular}{cc}
\hline$\geq \mathbf{0 , 3}$ & Valid \\
$<\mathbf{0 , 3}$ & Tidak Valid \\
\hline
\end{tabular}

Sumber : Sugiyono, 2016

\section{Pengujian Reliabilitas}

Suatu kuisoner dianggap reliabel jika jawaban responden atas pernyataanpernyataan mampu konsisten. Berikut kriteria uji reliabilitas :

Tabel 4 : Uji Reliabilitas

\begin{tabular}{cc}
\hline Cronbach Alpha & Keterangan \\
\hline$\geq \mathbf{0 , 6}$ & Reliabel \\
$<\mathbf{0 , 6}$ & Tidak Reliabel \\
\hline
\end{tabular}

Sumber : Sugiyono, 2012

\section{Uji Asumsi Klasik \\ Uji Normalitas}

Ghozali (2016: 154) uji normalitas diujikan untuk memperlihatkan apakah regresi dan variabel residual mempunyai distribusi normal.

\section{Uji Multikolonieritas}

$\begin{array}{ccr}\text { Ghozali } & \text { (2016:103), uji } \\ \text { multikolonieritas } & \text { diujikan } & \text { untuk }\end{array}$ memperlihatkan apakah model regresi ditemukan adanya kolerasi antar variabel bebas. Model regresi yang baik semestinya tak ditemukan hubungan antar variabel bebasnya.

\section{Uji Heteroskedastisitas}

Ghozali (2016: 134) uji heteroskedastisitas diujikan untuk membuktikan apakah suatu regresi terjadi ketidaksamaan variance dari residual satu pengamatan ke pengamatan lain. Model regresi yang baik semestinya tetap (homokedastisitas).

\section{Metode Pengolahan dan Analisis Data \\ Multiple Regression Analysis}

Nazir (2014: 410) jika hubungan antara satu variabel terikat dengan banyak variabel predictor dianalisis yang dipakai ialah multiple regression.

$$
\mathrm{Y}=\alpha+\beta_{1} X_{1}+\beta_{2} X_{2}+\beta_{3} X_{3}+\varepsilon
$$

\section{Moderated Regression Analysis}

Ghozali (2016:215) MRA ialah multiple regression dengan persamaan regresinya mengandung perkalian 2 (dua) ataupun lebih variabel predictor. 


$$
\begin{aligned}
\mathrm{Y}=\alpha+\beta_{1} X_{1} & +\beta_{2} X_{2}+\beta_{3} Z+\beta_{4} X_{1} Z \\
& +\beta_{5} X_{2} Z+\varepsilon
\end{aligned}
$$

\section{Koefisien Korelasi Berganda}

Koefisien korelasi merupakan angka yang memperlihatkan kuatnya kolerasi antara variabel predictor dengan variabel dependen. Untuk dapat menginterpretasikan kuatnya kolerasi antar 2 variabel tersebut, terdapat pedoman interprestasi, yaitu :

Tabel. 5: Pedoman Untuk Interpretasi Koefisien Korelasi

\begin{tabular}{cc}
\hline Interval nilai $r$ & Interprestasi \\
\hline $0,001-0,200$ & Sangat Lemah \\
$0,201-0,400$ & Lemah \\
$0,401-0,600$ & Cukup Kuat \\
$0,601-0,800$ & Kuat \\
$0,801-1,000$ & Sangat Kuat \\
\hline
\end{tabular}

Sumber : Sugiyono, 2012

\section{Koefisien Determinasi $\left(R^{2}\right)$}

Ghozali (2016: 95), koefisien determinasi diujikan untuk memperlihatkan sejauh apa predictor dalam menerangkan variabel dependen.

\section{Pengujian Hipotesis}

Uji F

Ghozali (2016:96) uji F adalah uji signifikansi keseluruhan dari regresi sampel. Penentuan hipotesis, sebagai berikut:

$\mathrm{H}_{\mathrm{o}}: \beta_{1}, \beta_{2}=0$; SAP dan SPIP tidak berpengaruh secara bersamasama terhadap kualitas LKPD Kota Bogor.

$\mathrm{H}_{\mathrm{a}}: \beta_{1}, \beta_{2} \neq 0$; SAP dan SPIP berpengaruh secara bersama-sama terhadap kualitas LKPD Kota Bogor.

Kriteria Keputusan Uji F

a. Bila $F_{\text {hitung }}>F_{\text {tabel }}$ dengan $\alpha=0.05$, Ha diterima Ho ditolak.

b. Bila $\mathrm{F}_{\text {hitung }} \leq \mathrm{F}_{\text {tabel }}$ dengan $\alpha=0.05$, Ho diterima Ha ditolak.

\section{Uji t}

Ghozali (2016: 97) Uji t ialah uji yang diujikan untuk pemperlihatkan sejauh apa efek satu variabel predictor secara parsial dalam menjelaskan variabel dependen.

Menyusun Hipotesis Nol $\left(H_{0}\right)$ dan hipotesis alternatif $\left(H_{\mathrm{a}}\right)$

$\mathrm{H}_{\mathrm{o}}: \beta_{1}=0$; SAP tidak mempunyai pengaruh terhadap kualitas LKPD.
$\mathrm{H}_{\mathrm{a}}: \beta_{1} \neq 0$; SAP mempunyai pengaruh terhadap kualitas LKPD.
$\mathrm{H}_{\mathrm{o}}: \beta_{2}=0$; SPIP tidak mempunyai pengaruh terhadap kualitas LKPD.
$\mathrm{H}_{\mathrm{a}}: \beta_{2} \neq 0$; SPIP mempunyai pengaruh terhadap kualitas LKPD.
$\mathrm{H}_{\mathrm{o}}: \beta_{3}=0$; Kompetensi SDM tidak memoderasi pengaruh SAP dan SPIP terhadap kualitas LKPD.
$\mathrm{H}_{\mathrm{a}}: \beta_{3} \neq 0$; Kompetensi SDM memoderasi pengaruh SAP dan SPIP terhadap kualitas LKPD.

Kriteria uji hipotesisnya adalah:

a. SAP bila $t_{\text {hitung }} \leq t_{\text {tabel }}$ dengan $\alpha=0.05$, Ho diterima Ha ditolak. Bila $t_{\text {hitung }}>t_{\text {tabel }}$ dengan $\alpha=0.05$, Ha diterima Ho ditolak.

b. SPIP bila $t_{\text {hitung }} \leq t_{\text {tabel }}$ dengan $\alpha=0.05$, Ho diterima Ha ditolak. Bila $t_{\text {hitung }}>t_{\text {tabel }}$ dengan $\alpha=0.05$, Ha diterima Ho ditolak.

c. KSDM bila $t_{\text {hitung }} \leq t_{\text {tabel }}$ dengan $\alpha=0.05$, Ho diterima Ha ditolak. $t_{\text {hitung }}>t_{\text {tabel }}$ dengan $\alpha=0.05$, Ha diterima Ho ditolak.

\section{HASIL DAN PEMBAHASAN}

Berdasarkan hasil jawaban mengenai karakteristik responden, bisa dilihat sebgai berikut:

Tabel 6 : Rekapitulasi Responden Berdasarkan Gender

\begin{tabular}{ccc}
\hline Jenis Kelamin & Jumlah & Persentase \\
\hline Laki-Laki & 72 & $55 \%$ \\
Perempuan & 59 & $45 \%$ \\
\hline Total & 131 & $100 \%$
\end{tabular}

Sumber : Data diolah, 2017

Tingkat proporsi responden menurut jenis kelamin yang terbesar adalah laki-laki sebanyak 72 orang (55\%), sebagian besar karyawan yang menjalankan fungsi akuntansi dan pelaporan adalah laki-laki.

Tabel 7 : Rekapitulasi Responden Berdasarkan

\begin{tabular}{ccc}
\multicolumn{2}{c}{ Usia } & \\
\hline Usia & Jumlah & Persentase \\
\hline $20-30$ & 8 & $6 \%$ \\
$31-40$ & 50 & $38 \%$ \\
\hline
\end{tabular}


Pengaruh SAP dan SPIP Terhadap Kualitas LKPD Kota Bogor....

\begin{tabular}{ccc}
\hline $41-50$ & 48 & $37 \%$ \\
$>50$ & 25 & $19 \%$ \\
\hline Total & 131 & $100 \%$
\end{tabular}

Tabel 10: Rekapitulasi Responden

Berdasarkan Latar Belakang

Pendidikan

Sumber : Data diolah, 2017

Kelompok usia responden yang terbesar adalah responden berusia dengan rentang 31-40 tahun yakni 50 orang (38\%)

Tabel 8 : Rekapitulasi Responden Berdasarkan

\begin{tabular}{ccc}
\multicolumn{2}{c}{ Masa Kerja } & \\
\hline Tahun & Jumlah & Persentase \\
\hline 1 s/d 10 & 31 & $24 \%$ \\
11 s/d 20 & 51 & $39 \%$ \\
21 s/d 30 & 36 & $27 \%$ \\
$>30$ & 13 & $10 \%$ \\
\hline Total & 131 & 100
\end{tabular}

Sumber : Data diolah, 2017

Masa kerja responden yang terbesar adalah antara $11 \mathrm{~s} / \mathrm{d} 20$ tahun yaitu 51 responden $(39 \%)$

Tabel 9 : Rekapitulasi Responden Berdasarkan Pendidikan

\begin{tabular}{ccc}
\hline Pendidikan & Jumlah & Persentase \\
\hline SMA & 13 & $10 \%$ \\
D1 & 0 & $0 \%$ \\
D2 & 0 & $0 \%$ \\
D3 & 9 & $7 \%$ \\
S1 & 66 & $50 \%$ \\
S2 & 43 & $33 \%$ \\
S3 & 0 & $0 \%$ \\
\hline Total & 131 & $100 \%$
\end{tabular}

Sumber : Data diolah, 2017

Tamatan terbesar pegawai adalah sarjana (S1), yakni 66 orang (50\%), rata-rata responden yang berkepentingan dengan fungsi akuntansi pemerintahan rata-rata berpendidikan sarjana (S1)

\begin{tabular}{ccc}
\hline Jurusan & Jumlah & Persentase \\
\hline Akuntansi & 31 & $24 \%$ \\
Manajemen & 45 & $34 \%$ \\
Pertanian & 2 & $1 \%$ \\
MIPA & 6 & $5 \%$ \\
Lain-lain & 47 & $36 \%$ \\
\hline Total & 131 & $100 \%$ \\
\hline
\end{tabular}

Sumber : Data diolah, 2017

Terbanyak berasal dari jurusan lainnya, yakni 47 orang $(36 \%)$, selanjutnya jurusan manajemen 45 orang (34\%), jurusan akuntansi 31 orang (24\%), MIPA 6 orang (5\%), dan terkecil jurusan pertanian 2 orang (1\%). Sehingga ratarata responden yang berkepentingan menjalankan fungsi akuntansi mempunyai jurusan pendidikan beragam.

Tabel 11 : Rekapitulasi Karakteristik Responden

\begin{tabular}{|c|c|c|c|}
\hline \multicolumn{2}{|c|}{$\begin{array}{c}\text { Kriteria } \\
\text { Responden }\end{array}$} & Karakteristik & $\begin{array}{c}\text { Orang/Per } \\
\text { sentase }\end{array}$ \\
\hline \multicolumn{2}{|c|}{ Jenis Kelamin } & Laki-laki & $72 / 55 \%$ \\
\hline \multicolumn{2}{|r|}{ Usia } & $31-40$ & $50 / 38 \%$ \\
\hline \multicolumn{2}{|c|}{ Masa Kerja } & $11 \mathrm{~s} / \mathrm{d} 20$ & $51 / 39 \%$ \\
\hline \multicolumn{2}{|c|}{ Pendidikan } & S1 & $66 / 50 \%$ \\
\hline \multicolumn{2}{|c|}{$\begin{array}{c}\text { Latar Belakang } \\
\text { Pendidikan }\end{array}$} & Lain-lain & $47 / 36 \%$ \\
\hline \multicolumn{4}{|c|}{ Sumber : Data diolah, 2017} \\
\hline \multicolumn{4}{|c|}{ Tabel 12 : Rekapitulasi Tanggapan Responden } \\
\hline No & Variabel & $\begin{array}{c}\text { Nilai Rata- } \\
\text { rata Skor } \\
\text { Tanggapan }\end{array}$ & Keterangan \\
\hline 1 & $\operatorname{SAP}\left(X_{1}\right)$ & 4,36 & Sangat Setuju \\
\hline 2 & $\operatorname{SPIP}\left(X_{2}\right)$ & 4,35 & Sangat Setuju \\
\hline 3 & KSDM (Z) & 4,28 & Sangat Setuju \\
\hline 4 & $\begin{array}{l}\text { Kualitas } \\
\text { LKPD (Y) }\end{array}$ & 4,36 & Sangat Setuju \\
\hline
\end{tabular}




\begin{tabular}{clccc}
\hline No & Variabel & rhitung & rkritis & $\begin{array}{c}\text { Keteran } \\
\text { gan }\end{array}$ \\
\hline 1 & SAP & 0,620 & 0,3 & Valid \\
2 & SPIP & 0,588 & 0,3 & Valid \\
3 & KSDM & 0,641 & 0,3 & Valid \\
4 & Kualitas & 0,672 & 0,3 & Valid \\
& LKPD & & & \\
\hline
\end{tabular}

Sumber : Output SPSS Versi 20

Sumber : Data diolah, 2017

\begin{tabular}{llccc}
\hline No & Variabel & $\begin{array}{c}\text { Cronb } \\
\text { ach } \\
\text { Alpha }\end{array}$ & rkritis & $\begin{array}{c}\text { Keteran } \\
\text { gan }\end{array}$ \\
\hline 1 & SAP & 0,910 & 0,6 & Reliabel \\
2 & SPIP & 0,838 & 0,6 & Reliabel \\
3 & KSDM & 0,871 & 0,6 & Reliabel \\
4 & Kualitas & 0,902 & 0,6 & Reliabel \\
& LKPD & & & \\
\hline
\end{tabular}

Rata-rata responden beranggapan sangat setuju bahwa penerapan SAP, SPIP dan kompetensi SDM akan mempengaruhi criton (Y).

\section{Analisis Statistik Deskriptif}

Tabel 13 : Analisis Statistik Deskriptif

\begin{tabular}{lcccc}
\hline & SAP & SPIP & KSDM & LKPD \\
\hline $\mathrm{N}$ & 131 & 131 & 131 & 131 \\
Range & 17 & 9 & 10 & 8 \\
Minimum & 43 & 21 & 20 & 27 \\
Maximum & 60 & 30 & 30 & 35 \\
Sum & 6861 & 3424 & 3381 & 4002 \\
Mean & 52,37 & 26,14 & 25,81 & 30,55 \\
Std.Deviation & 4,610 & 2,556 & 2,706 & 2,782 \\
Variance & 21,251 & 6,535 & 7,325 & 7,742 \\
\hline
\end{tabular}

Sumber : Output SPSS Versi 20

1. Variabel SAP diperoleh niai rata-rata (mean) sebesar 52,37, simpangan baku sebesar 4,610, keragaman data variabel SAP sebesar 21, 251, total nilai tertinggi 60 dan terendah 43.

2. Variabel SPIP diperoleh niai rata-rata (mean) sebesar 26,14, simpangan baku sebesar 2,556, keragaman data SPIP sebesar 6,535 , total nilai tertinggi 30 dan terendah 21.

3. Variabel Kompetensi SDM diperoleh niai rata-rata (mean) sebesar 25,81, simpangan baku sebesar 2,706, keragaman data variabel Kompetensi SDM sebesar 7, 235, total nilai tertinggi 30 dan terendah sebesar 20.

4. Variabel Kualitas LKPD diperoleh niai ratarata (mean) sebesar 30,55, simpangan baku sebesar 2,782, keragaman data variabel LKPD sebesar 7,724, total nilai tertinggi 35 dan total nilai terendah 27.

\section{Pengujian Instrumen Uji Validitas}

Tabel 14 : Rekapitulasi Uji Validitas Semua pernyataan dari variabel SAP, SPIP, KSDM, LKPD dikatakan valid sebab rhitung masing-masing pernyataan $>$ rkritis.

\section{Uji Reliabilitas}

Tabel 15 : Rekapitulasi Uji Reliabilitas Sumber : Output SPSS Versi 20

Berdasarkan tabel tersebut Semua pernyataan variabel SAP, SPIP, KSDM, LKPD dinyatakan reliabel karena Cronbach's Alpha masing-masing pernyataan $>$ rkritis.

\section{Uji Asumsi Klasik Uji Normalitas}

1. Metode grafik normal $p$-p plot dan grafik histogram

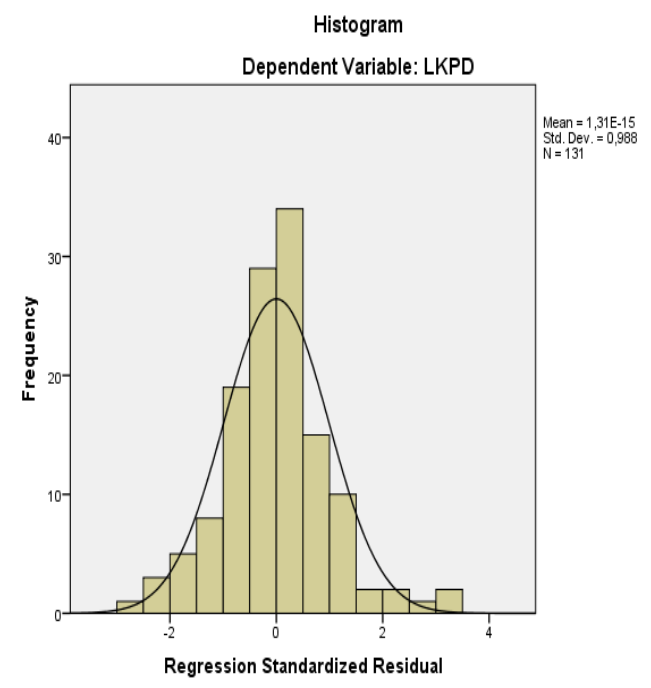

Sumber : Output SPSS Versi 20

Gambar 1 Grafik Histogram 


\begin{tabular}{|c|c|c|}
\hline \multirow{3}{*}{ Model } & \multicolumn{2}{|c|}{ Coefficientsa } \\
\hline & \multicolumn{2}{|c|}{ Collinearity Statistics } \\
\hline & Tolerance & VIF \\
\hline \multirow{4}{*}{$\begin{aligned} & \text { (Constant) } \\
& 1 \text { SAP } \\
& \text { SPIP } \\
& \text { KSDM }\end{aligned}$} & & \\
\hline & ,579 & 1,727 \\
\hline &, 585 & 1,709 \\
\hline & 619 & 1,616 \\
\hline
\end{tabular}

a. Dependent Variable: LKPD

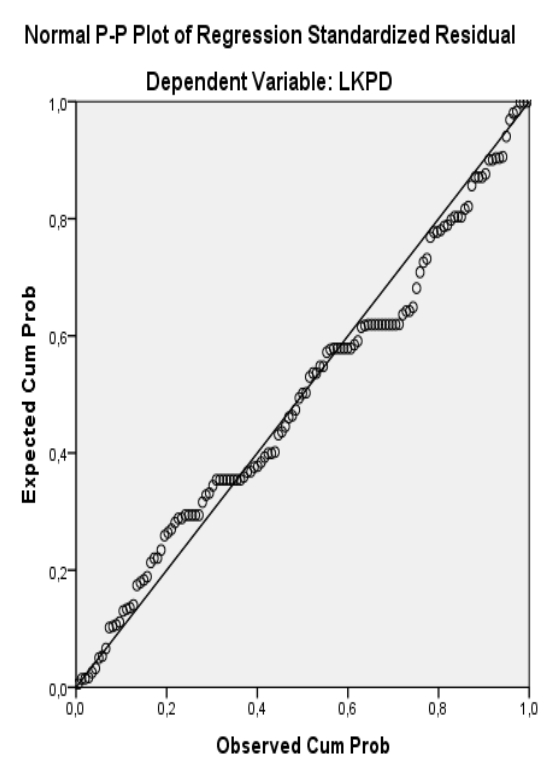

Sumber : Output SPSS Versi 20

Gambar 2 Grafik Normal P-P Plot grafik histogram menampilkan model penyebaran normal dengan kurva berbentuk lonceng. Normal $p$ - $p$ plot titik-titik terpencar dekat garis diagonal juga arahnya mengikuti garis diagonal. Bisa disimpulkan data terdistribusi normal, dan regresi sudah mendapati asumsi normalitas.

2 Metode Statistikal One Sample K-S

Tabel 16 : Kolmogorov-Smirnov One Sample Kolmogorov-Smirnov Test

Sumber : Output SPSS Versi 20

Berdasarkan hasil pengujian one sample kolmogorov-smirnov nilai Asymp Significant. (two-tailed) yaitu sebesar sebesar 0,165 . Hasil diatas memperlihatkan data sudah dianggap normal disebabkan hasil Asymp. Significant. (two-tailed) >0,05.

\section{Uji Multikolonieritas}

Uji multikolineriaritas bertujuan untuk mendeteksi ada tidaknya gejala korelasi yang signifikan antara variabel BEBAS.
Tabel 17 : Hasil Uji Multikolonieritas Sumber : Output SPSS Versi 20

Variabel SAP memiliki nilai VIF 1,727, Sedangkan nilai tolerance sebesar 0,579. Variabel SPIP memiliki nilai VIF 1,709, Sedangkan nilai tolerance sebesar 0,585. Variabel KSDM memiliki nilai VIF 1,616. Sedangkan nilai tolerance sebesar 0,619 semua variabel tersebut memiliki nilai VIF $<10$ dan memiliki nilai tolerance $>0,1$ lantas bisa dikatakan model regresi tak mengalami masalah multikolineriaritas.

\section{Uji Heteroskedastisitas}

Uji heteroskedastisitas dilakukan untuk menemukan terdapat atau tidaknya gejala ketidaksamaan varian residual untuk seluruh pengamatan di model regresi

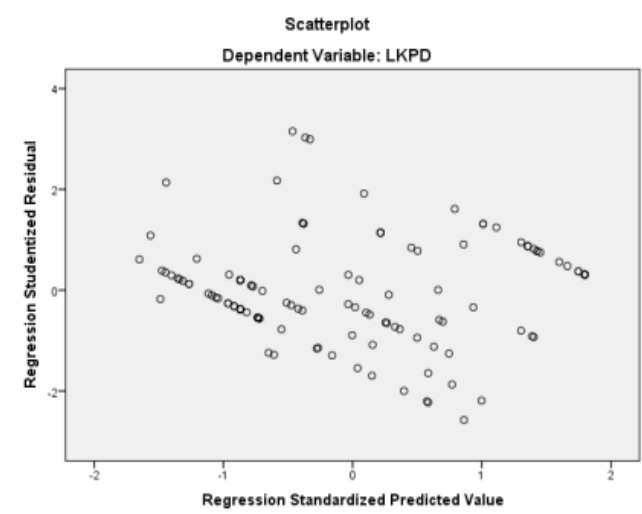

\begin{tabular}{llr}
\hline & Unstandardized Residual \\
\hline $\mathrm{N}$ & & 131 \\
Normal & Mean & $0 \mathrm{E}-7$ \\
Parametersa,b & Std. & 1,7283 \\
& Deviation & 5697 \\
& Absolute &, 098 \\
Most Extreme & Positive &, 098 \\
Differences & Negative &,- 066 \\
Kolmogorov-Smirnov Z & 1,116 \\
Asymp. Sig. (2-tailed) &, 165 \\
\hline
\end{tabular}

Sumber : Output SPSS Versi 20 Gambar 3 Grafik Scatterplot

Tampak titik-titik tersebar dengan acak, menyebar diatas ataupun dibawah angka nol di sumbu Y. Hasil itu memperlihatkan tak terdapat masalah heteroskedastisitas, lantas regresi layak digunakan.

\section{Analisa Data}

Persamaan Regresi Linier Berganda

Multiple regression analysis diujikan untuk memperlihatkan hubungan fungsional 
antara beberapa variabel predictor secara bersama-sama terhadap criton (Y).

Tabel 18 : Multiple regression analysis Sumber : Output SPSS Versi 20

Berdasarkan tabel 4.17 diatas diketahui bahwa nilai dari persamaan regresi yaitu sebagai berikut:

$$
\begin{gathered}
\mathrm{Y}=5,389+0,108 X_{1}+0,187 X_{2}+0,568 X_{3} \\
+\varepsilon
\end{gathered}
$$

\section{Koefisien Korelasi Ganda}

Tabel 4.19 : Koefesien Kolerasi Berganda Sumber ; Output SPSS Versi 20

Diperoleh nilai $\mathrm{R}$ sebesar 0,784 berada pada interval nilai $R(0,601-0,800)$ dengan kekuatan hubungan yang kuat, sehingga kekuatan hubungan yang kuat diantara variabel predictor terhadap variabel criton (Y).

Selanjutnya korelasi parsial (partial correlation) antara SAP dengan kualitas LKPD sebesar 0,561 (56,1\%) yang menyatakan bahwa korelasinya cukup kuat. SPIP dengan kualitas LKPD sebesar 0,616 (61,6\%) yang menyatakan bahwa korelasinya kuat. KSDM dengan kualitasLKPD sebesar 0,719 (71,9\%) yang menyatakan bahwa korelasinya kuat.

\section{Koefisien Determinasi}

Koefisien determinasi diujikan untuk melihat sejauh apa kontribusi variabel predictor terhadap variabel criton $(\mathrm{Y})$.

Tabel 20 : Koefisien Determinasi Model Summaryb

\begin{tabular}{lcccc}
\hline $\begin{array}{l}\text { Mo } \\
\text { del }\end{array}$ & R & $\begin{array}{c}\text { R } \\
\text { Square }\end{array}$ & $\begin{array}{c}\text { Adjusted R } \\
\text { Square }\end{array}$ & $\begin{array}{c}\text { Std. Error of } \\
\text { the Estimate }\end{array}$ \\
\hline 1 &, $784^{a}$ &, 614 &, 605 & 1,749
\end{tabular}

a. Predictors: (Constant), KSDM, SPIP, SAP

b. Dependent Variable: LKPD

Sumber : Output SPSS Versi 20

Diperoleh angka $\mathrm{R}^{2} \quad(R \quad$ square $)$ sebesar 0,614 atau $(61,4 \%)$. Hasil tersebut memperlihatkan kontribusi variabel predictor terhadap variabel criton (Y) sebesar 61,4\%, sedangkan sisanya 38,6\% dipengaruhi oleh variabel-variabel lainnya yang tak dianalisa di penelitian ini.

Coefficients ${ }^{\mathrm{a}}$

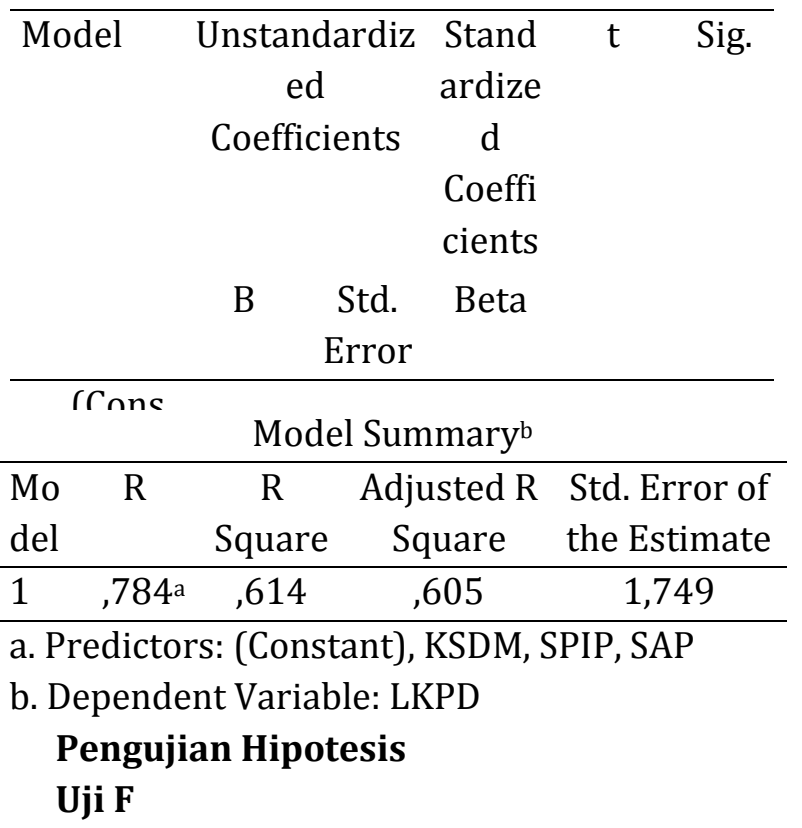

Uji F diujikan untuk memperlihatkan efek simultan penerapan SAP dan SPIP terhadap kualitas LKPD.

Tabel 21 : UjiF

\begin{tabular}{|c|c|c|c|c|c|}
\hline Model & $\begin{array}{c}\text { Sum of } \\
\text { Squares }\end{array}$ & Df & $\begin{array}{l}\text { Mean } \\
\text { Square }\end{array}$ & $\mathrm{F}$ & Sig. \\
\hline $\begin{array}{l}\text { Regressi } \\
\text { on }\end{array}$ & 618,089 & 3 & $\begin{array}{r}206,03 \\
0\end{array}$ & $\begin{array}{r}67,3 \\
79\end{array}$ &, $000^{\mathrm{b}}$ \\
\hline Residual & 388,338 & 127 & 3,058 & & \\
\hline Total & $\begin{array}{r}1006,42 \\
7\end{array}$ & 130 & & & \\
\hline
\end{tabular}
ANOVA

a. Dependent Variable: LKPD

b. Predictors: (Constant), KSDM, SPIP, SAP

Sumber : Output SPSS Versi 20

Diketahui $\quad F_{\text {hitung }}$ sebesar 67,379, sedangkan $\mathrm{F}$ tabel sebesar 2,68, maka $\mathrm{F}_{\text {hitung }}>$ $F_{\text {tabel }}(67,379>2,68)$ dengan nilai signifikansi F sebesar 0,00 $<0,05$, Ha diterima dan Ho ditolak. Berarti SAP dan SPIP secara simultan berpengaruh dan signifikan terhadap variabel Y(kualitas LKPD Bogor).

\section{Uji t}

Uji t diujikan untuk memperlihatkan efek secara individual variabel predictor terhadap variabel criton $(\mathrm{Y})$. 


\begin{tabular}{|c|c|c|c|c|c|}
\hline & & bel 22 & $\begin{array}{l}\text { : Uji t } \\
\text { ents }\end{array}$ & & \\
\hline Model & $\begin{array}{l}\text { Unstan } \\
\text { d Coeff }\end{array}$ & $\begin{array}{l}\text { ardize } \\
\text { cients }\end{array}$ & $\begin{array}{l}\text { Standa } \\
\text { rdized }\end{array}$ & $\mathrm{t}$ & Sig. \\
\hline & B & $\begin{array}{l}\text { Std. } \\
\text { Error }\end{array}$ & Beta & & \\
\hline $\begin{array}{l}\text { (Const } \\
\text { ant) }\end{array}$ & 5,389 & 1,917 & & 2,812 & ,006 \\
\hline SAP & 108 & ,044 & 178, & 2,459 & 015, \\
\hline 1 SPID & & & & & \\
\hline SPIP & 181, & ,078 & 17/1 & 2,380 & 019, \\
\hline KSDM & ,568 & 072 & ,552 & 7,880 & 000 \\
\hline
\end{tabular}

a. Dependent Variable: LKPD

Sumber : Output SPSS Versi 20

Hasil pengujian untuk SAP sebesar 2,459 , sedangkan $t_{\text {tabel }}$ sebesar 1,97882 , maka $t_{\text {hitung }}>t_{\text {tabel }}(2,459>1,9782)$ dengan tingkat signifikan sebesar 0,015<0,05, Ha diterima dan Ho ditolak. Kondisi ini memperlihatkan ternyata SAP mempunyai pengaruh parsial terhadap variabel Y (kualitas LKPD Kota Bogor). Untuk SPIP sebesar 2,380, maka $t_{\text {hitung }}>t_{\text {tabel }}(2,380>1,9782)$ dengan tingkat signifikan sebesar 0,019<0,05, Ha diterima dan Ho ditolak. Kondisi ini memperlihatkan ternyata SPIP mempunyai pengaruh parsial terhadap variabel Y (kualitas LKPD Kota Bogor).

\section{Moderated Regresion Analysis}

MRA ini diujikan untuk memperlihatkan efek variabel interaksi pada variabel dependennya. Kriteria uji MRA apabila $t_{\text {hitung }}>t_{\text {tabel }}$ dengan $\alpha=0,05$, Ha diterima dan Ho ditolak, sedangkan bila $t_{\text {hitung }}$ $\leq \mathrm{t}_{\text {tabel }}$ dengan $\alpha=0,05$, Ho diterima dan Ha ditolak.

\section{Uji MODERASI}

Uji MODERASI 1 dilakukan untuk melihat variabel Kompetensi SDM (Z) memoderasi hubungan antara Penerapan SAP $\left(\mathrm{X}_{1}\right)$ dengan LKPD $(\mathrm{Y})$.

\begin{tabular}{|c|c|c|c|c|c|}
\hline \multirow[t]{2}{*}{ Model } & \multicolumn{2}{|c|}{$\begin{array}{l}\text { Unstandardized } \\
\text { Coefficients }\end{array}$} & \multirow{2}{*}{$\begin{array}{c}\text { Standardized } \\
\text { Coefficients } \\
\text { Beta }\end{array}$} & \multirow[t]{2}{*}{$\mathrm{t}$} & \multirow[t]{2}{*}{ Sig. } \\
\hline & B & $\begin{array}{l}\text { Std. } \\
\text { Error }\end{array}$ & & & \\
\hline (Constant) & 5,389 & 1,917 & & 2,812 & ,006 \\
\hline SAP & 108 & ,044 & 178 & 2,459 & 015 \\
\hline SPIP & 187 & ,078 & 171 & 2,380 & 019 \\
\hline KSDM & ,568 & ,072 & ,552 & 7,880 & ,000 \\
\hline SAP* KSDM & ,501 & ,058 & ,947 & 8,655 & 000 \\
\hline F Ratio & 89,974 & & & & \\
\hline Sig. F &, 000 & & & & \\
\hline Adj. R Square & ,577 & & & & \\
\hline
\end{tabular}

Sumber : Data diolah, 2017

Hasil untuk SAP*KSDM sebesar 8,655, maka $t_{\text {hitung }}>t_{\text {tabel }}(8,655>1,9782)$ dengan tingkat signifikan senilai $0.000<0.05$, Ha diterima dan Ho ditolak. Berarti KSDM

Uji MODERASI 2

Uji MODERASI 2 dilakukan untuk melihat variabel SDM memoderasi hubungan memoderasi hubungan SAP terhadap variabel dependen (kualitas LKPD Kota Bogor) dengan sifat yang memperlemah hubungan SAP pada variabel LKPD (Y).

SPIP $\left(\mathrm{X}_{2}\right)$ terhadap variabel kualitas LKPD Kota Bogor $(\mathrm{Y})$. 
Tabel 24 : Uji Moderasi 2

\begin{tabular}{|c|c|c|c|c|c|}
\hline \multirow[t]{2}{*}{ Model } & \multicolumn{2}{|c|}{$\begin{array}{l}\text { Unstandardized } \\
\text { Coefficients }\end{array}$} & \multirow{2}{*}{$\begin{array}{c}\text { Standardized } \\
\text { Coefficients } \\
\text { Beta }\end{array}$} & \multirow[t]{2}{*}{$\mathrm{t}$} & \multirow[t]{2}{*}{ Sig. } \\
\hline & B & $\begin{array}{l}\text { Std. } \\
\text { Error }\end{array}$ & & & \\
\hline (Constant) & 5,389 & 1,917 & & 2,812 & ,006 \\
\hline SAP & 108 & ,044 & 178 & 2,459 & 015 \\
\hline SPIP & 187 & ,078 & 171 & 2,380 & ,019 \\
\hline KSDM & ,568 & ,072 & ,552 & 7,880 & ,000 \\
\hline SPIP* KSDM &, 504 & ,058 & 1,004 & 8,716 & ,000 \\
\hline F Ratio & 89,245 & & & & \\
\hline Sig. F &, 000 & & & & \\
\hline R Square & ,582 & & & & \\
\hline Adj. R Square &, 576 & & & & \\
\hline
\end{tabular}

Sumber : Data diolah, 2017

Hasil untuk SPIP*KSDM sebesar 8,716. maka $t_{\text {hitung }}>t_{\text {tabel }}(8,716>1,9782)$ dengan tingkat signifikan senilai $0,000<0,05$, Ha diterima dan Ho ditolak. Bermakna Kompetensi SDM memoderasi hubungan SPIP

Terhadap variabel Y (kualitas LKPD Kota Bogor). dengan sifat yang memperlemah hubungan SPIP terhadap variabel LKPD (Y). Dan dapat disimpulkan variabel $\mathrm{Z}$ merupakan Quasi Moderator. Jenis variabel moderator ini

Uji Moderasi 1
SPIP $\left(\mathrm{X}_{2}\right)$ terhadap variabel kualitas LKPD Kota Bogor (Y).

Uji Moderasi 2 adalah variabel moderator yang akan memodifikasi bentuk hubungan antara criton $(\mathrm{Y})$ dan predictor $(\mathrm{X})$. Variabel moderator $(\mathrm{Z})$ berperan sebagai predictor variable (bebas) dan sekaligus mempunyai interaksi dengan variabel predictor lainnya. Hasil ini disebabkan variabel $\mathrm{Z}$ tersebut dapat berlaku sebagai moderator juga sekaligus sebagai variabel independen. memoderasi hubungan SAP terhadap variabel dependen (kualitas LKPD Kota Bogor) dengan sifat yang memperlemah hubungan SAP pada variabel LKPD (Y). 


\section{Pengaruh Penerapan SAP dan SPIP terhadap Kualitas LKPD Kota Bogor}

Pengaruh SAP dan SPIP terhadap kualitas LK (Laporan Keuangan)Pemkot Bogor menunjukan bahwa kualitas LK pemerintah dapat diukur dari sejauh mana penerapan SAP dan SPIP. Hasil pengolahan statistik menunjukan bahwa pengaruh SAP dan SPIP secara bersama-sama menghasilkan angka yang positif. Hasil tersebut menjelaskan terdapat pengaruh yang positif dan diartikan bila penerapan SAP dan SPIP baik, cendrung akan menghasilkan LKPD yang baik pula. Hasil penelitian ini juga mendukung penelitian dari Sopianti (2016).

Pengaruh penerapan SAP dalam menentukan kualitas LK di Kota Bogor karena SAP tersebut merupakan pedoman dan acuan wajib bagi SKPD Kota Bogor sebagai entitas akuntansi untuk perlakuan dan pencatatan transaksi-transaksi ekonomi yang terjadi, sehingga SAP memiliki kekuatan hukum serta berlaku umum. Penelitian ini sesuai dengan teori Bastian (2010: 138) penerapan SAP yang sesuai dalam pemenuhan kewajiban pelaporan pertanggungjawaban keuangan daerah merupakan penentu atas kualitas dari LK (laporan keuangan) yang dihasilkan, dan mempunyai kekuatan hukum dalam upaya menigkatan kualitas LK (Laporan keuangan) pemerintah. Hasil penelitian ini juga mendukung penelitian dari Saputa (2015).

Sedangkan pengaruh SPIP pada kualitas LK (laporan keuangan) Pemkot Bogor dikarenakan SPIP yang diimplementasikan dengan efektif dan juga diterapkan oleh pimpinan hingga pegawainya akan menentukan aktivitas pemerintah untuk mengelola dana publik termasuk pembuatan LK akan terhindar dari penyimpangan maupun tindakan-tindakan kurang etis yang bisa menghambat proses pembuatan LK pemerintah. Penelitian ini sesuai dengan teori Mahmudi (2011:252) SPIP bertujuan untuk membuat LK yang akurat, relevan, dan andal. Hasil pembuktian ini mendukung penelitian dari Soimah (2014).

\section{Kompetensi SDM Memoderasi Pengaruh Penerapan SAP dan SPIP terhadap Kualitas LKPD Kota Bogor}

Tantangan untuk menerapkan akuntansi pemerintahan berbasis akrual salah satunya SDM perlu memiliki pengetahuan, pemahaman yang cukup mengenai akuntansi pemerintahan, SDM juga harus memahami dengan tepat penerapan SPI di dalam suatu entitas secara konsisten. Hasil uji statistik menunjukan variabel KSDM Kota Bogor memperlemah hubungan SAP dan SPIP terhadap Kualitas LK (laporan keuangan) Pemerintah Kota Bogor. Hasil itu disebabkan responden yang berkepentingan dalam melakukan pembuatan LK pada setiap SKPD Kota Bogor sebagian besar bukan merupakan SDM berlatar belakang pendidikan Akuntansi.

Hendaknya LKPD Kota Bogor disusun oleh aparatur yang mempunyai kemampuan di bidang akuntansi pemerintahan sehingga meminimalisir resiko kesalahan pembuatan laporan keuangan. SDM yang memiliki kecakapan sesuai bidangnya selain dapat mempengaruhi secara langsung kualitas LKPD dapat pula meningkatkan pemahaman terhadap penerapan SAP dan SPIP. Walaupun Kompetensi SDM mampu memoderasi SAP dan SPIP terhadap kualitas LK (laporan keuangan) Pemkot Bogor dan mayoritas pegawai berpendidikan S1 belum menjamin akan meningkatkan kualitas LKPD Kota Bogor apabila penempatan pegawai tak sesuai dengan bidang yang dikuasainya. Bastian (2006:55) menyatakan bahwa proses pembuatan LK pemerintah yang berkualitas membutukan KSDM yang menguasai Akuntansi Pemerintahan. Kegagalan SDM pemerintah daerah untuk mengimplementasikan akuntansi pemerintahan nantinya mengakibatkan suatu kesalahan LK pemerintah yang dihasilkan dan ketidaksamaan LK dengan SAP (Warisno, 2009). Arens (2012:290) menyatakan tujuan entitas dicapai dengan maksimal bisa diperoleh melewati upaya pengendalian yang diterapkan oleh SDM yang mempunyai kemampuan secara efisien juga efektif. 


\section{KESIMPULAN}

1. Karakteristik responden didominasi oleh laki-laki, dengan usia berkisar antara 31-40 tahun. Rata-rata masa kerja responden berkisar antara $11 \mathrm{~s} / \mathrm{d} \quad 20$ tahun, pendidikan terakhir sarjana (S1) dengan jurusan yang terbanyak berasal dari jurusan lainnya selain akuntansi, manajemen, MIPA dan pertanian.

2. SAP dan SPIP secara simultan memiliki pengaruh terhadap kualitas LK (laporan keuangan) Pemerintah Kota Bogor.

3. SAP dan SPIP secara individu (parsial) berpengaruh terhadap kualitas LK (laporan keuangan) Pemerintah Kota Bogor.

\section{SARAN}

1. Penempatan SDM yang disesuaikan dengan background pendidikannya, memilih SDM yang berpengalaman di bidang accounting sehingga meminimalisir kesalahan dalam proses penyusunan LKPD Kota Bogor. Serta diberikanya pelatihan-pelatihan kepada pegawai kuhusnya di bidang keuangan.

2. Untuk peneliti selanjutnya agar memasukan variabel lainnya yang bisa menentukan kualitas LK pemerintah daerah, seperti komitmen organisasi, peranan Inspektorat Daerah, pemanfaatan teknologi dan informasi, serta Sistem Akuntansi Keuangan Daerah (SKAD).

3. Untuk peneliti selanjutnya, disarankan agar melengkapi metode survei dengan wawancara.

\section{DAFTAR PUSTAKA}

Arens, A.A, Randal J, dan Beasly, M.S. 2012. Auditing and Assurance Service: An Integrated Approach. 14th Edition. Pearson Prentice Hall, New Jersey.

Bastian, Indra, 2006, Akuntansi Sektor Publik: Suatu Pengantar, Erlangga, Jakarta. 2010, Akuntansi Sektor Publik, Edisis Ketiga, Erlangga, Jakarta.

Ghozali, Imam, 2016, Aplikasi Analisis Multivariate dengan Program SPSS, Edisi Keempat, Badan Penerbit Universitas Diponogor, Semarang.

Halim, Abdul dan Kusufi, Muhammad Syam, 2014, Akuntansi Sektor Publik, Edisi 2, Salemba Empat, Jakarta.
Mahmudi, 2011, Akuntansi Sektor Publik, UII Pres, Yogyakarta.

Nazir, Moh, 2014, Metode Penelitian, Ghalia Indonesia, Bogor.

Pemendagri, Nomor 64 Tahun 2013, Penerapan SAP Berbasis Akrual pada Pemerintah Daerah.

Peraturan Pemerintah, Nomor 60 Tahun 2008, Sistem Pengendalian Intern Pemerintah. Nomor 71 Tahun 2010,

Standar Akuntansi Pemerintah.

Saputra, Ade, 2015, Pengaruh Penerapan SAP, Sistem Pengendalian Intern, dan Kompetensi SDM terhadap Kualitas Laporan Keuangan Pada SKPD Kabupaten Kampar, Jurnal Organisasi Publik, Volume 02 Nomor 2.

Soimah, Siti, 2014, Pengaruh Kapasitas SDM, Pemanfaatan Teknologi Informasi Dan SPIP Terhadap kualitas Laporan Keuangan Pemerintah Daerah Kabupaten Bengkulu Utara, Skripsi Sarjana, Universitas Bengkulu.

Sopianti, Ranti, 2016, Pengaruh Penerapan SAP dan SPIP terhadap Kualitas LKPD Kabupaten Cianjur, Skripsi Sarjana, Fakultas Ekonomi Universitas Djuanda, Bogor.

Sugiyono, 2012, Memahami Penelitian Kualitatif, Penerbit Alfabeta, Bandung. 2016, Metode Penelitian Manajemen, Penerbit Alfabeta, Bandung.

Tantriani, Sukmaningrum 2012, Analisis

Faktor-Faktor yang Mempengaruhi Informasi Laporan Keuangan Pemerintah Daerah (Studi Empiris pada Pemerintah Kabupaten dan Kota Semarang), Skripsi Sarjana, Universitas Diponegoro.

Warisno, 2009, Faktor-faktor yang Mempengaruhi Kinerja Satuan Kerja Perangkat Daerah di Lingkungan Pemerintah Provinsi Jambi, Tesis Universitas Sumatera Utara. 